CZASOPISMO INŻYNIERII LA¿DOWEJ, ŚRODOWISKA I ARCHITEKTURY JOURNAL OF CIVIL ENGINEERING, ENVIRONMENT AND ARCHITECTURE

JCEEA, t. XXXIII, z. 63 (3/16), lipiec-wrzesień 2015, s. 399-411

Tomasz SALATA ${ }^{1}$

Barbara PRUS ${ }^{2}$

Krzysztof GAWROŃSKI ${ }^{3}$

\title{
OCENA ROZWIĄZAŃ PLANISTYCZNYCH Z WYKORZYSTANIEM PRZESTRZENNYCH BAZ DANYCH W ASPEKCIE SKALOWALNOŚCI ROZWOJU ZABUDOWY
}

\begin{abstract}
Artykuł prezentuje możliwości zastosowania metod geomatycznych do oceny jakości sporządzonych rysunków miejscowych planów zagospodarowania przestrzennego w aspekcie możliwości ich kontrolowanego rozwoju. Skalowalność, badana $\mathrm{w}$ poniższym artykule jest miarą możliwego powielania rozwiązań planistycznych z zakresu komunikacji, optymalizacji wielkości działek budowlanych, rozwoju terenów podmiejskich i racjonalnego wykorzystywania możliwych terenów inwestycyjnych dla budownictwa mieszkaniowego. Analizę przestrzenną wykonano w oparciu o techniki GIS i funkcje zaimplementowane do obsługi przestrzennych baz danych. Skorzystano $\mathrm{z}$ wolnego oprogramowania: SQLite/Spatialite, SpatiaLite_GUI, QGIS.
\end{abstract}

Słowa kluczowe: geoinformatyka, wolne oprogramowanie GIS, planowanie miejscowe, skalowaność MPZP

\section{Wstęp}

Według założeń ustawy o planowaniu i zagospodarowaniu przestrzennym [12] ład przestrzenny jest to ukształtowanie przestrzeni, które tworzy harmonijną całość oraz uwzględnia w uporządkowanych relacjach uwarunkowania i wymagania funkcjonalne, społeczno-gospodarcze, środowiskowe, kulturowe oraz kompozycyjno-estetyczne. Ten idealny stan zagospodarowania przestrzennego powinien

\footnotetext{
${ }^{1}$ Autor do korespondencji / corresponding author: Tomasz Salata, Uniwersytet Rolniczy w Krakowie, Katedra Gospodarki Przestrzennej i Architektury Krajobrazu, ul. Balicka 253c, 30-149 Kraków, tel. (12) 66245 43, kgpiak@ur.krakow.pl

2 Barbara Prus, Uniwersytet Rolniczy w Krakowie, Katedra Gospodarki Przestrzennej i Architektury Krajobrazu, ul. Balicka 253c, 30-149 Kraków, tel. (12) 66245 43, kgpiak@ur.krakow.pl

3 Krzysztof Gawroński, Uniwersytet Rolniczy w Krakowie, Katedra Gospodarki Przestrzennej i Architektury Krajobrazu, ul. Balicka 253c, 30-149 Kraków, tel. (12) 6624543 , kgpiak@ur.krakow.pl
} 
odpowiadać kryteriom: funkcjonalnym, estetycznym, społecznym, gospodarczym, technicznym i przyrodniczym. Ład przestrzenny uważany jest za cel nadrzędny, za pożądany w określonym czasie i miejscu stan zagospodarowania przestrzennego. Ład przestrzenny jest realizowany między innymi poprzez politykę planistyczną władz gminy wyrażoną w procesie planowania miejscowego, w ramach którego na poziomie gminy powstają: studia uwarunkowań i kierunków zagospodarowania przestrzennego oraz miejscowe plany zagospodarowania przestrzennego. Zgodnie $\mathrm{z}$ zapisami ustawowymi w miejscowych planach zagospodarowania przestrzennego określa się kierunki rozwoju gmin, w tym między innymi:

- dopuszczalny zakres zmian w strukturze przestrzennej gminy oraz w przeznaczeniu terenów, a także ograniczenia dotyczące tych zmian,

- minimalne i maksymalne parametry oraz wskaźniki urbanistyczne do zagospodarowania i użytkowania terenu z uwzględnieniem ładu przestrzennego.

Ograniczenia dla realizacji ładu przestrzennego stanowi wiele czynników, zarówno tych o charakterze ekonomicznym jak i fizjograficznym czy historycznym. Planowanie przestrzenne na terenach już zagospodarowanych powinno łączyć elementy zagospodarowania już istniejące $\mathrm{z}$ nowopowstającymi. Ważną cechą przestrzeni jest ograniczoność, stąd rozwiązania planistyczne powinny dążyć do jak najbardziej racjonalnego jej wykorzystania [11], [5].

W ostatnich latach można zaobserwować niepokojące zjawisko przeznaczania znacznych powierzchni rolniczej przestrzeni produkcyjnej na cele zabudowy mieszkaniowej [8]. Zabudowa powstaje wzdłuż dróg, w istniejących nieciągłościach lecz także na terenach wcześniej niezamieszkałych. Szczególnie dużą presją urbanizacyjną objęte są tereny położone na peryferiach miast [1], [10]. Tam też można zaobserwować zjawisko suburbanizacji [9], które przejawia się przeznaczaniem obszarów użytkowanych rolniczo na strefy zabudowane i zurbanizowane posiadające charakter quasi miejski [7].

Przyjęte rozwiązania planistyczne zawarte $\mathrm{w}$ dokumentach planistycznych będą w dużej mierze zależne od zastanego stanu zagospodarowania przestrzennego. Na obszarach wiejskich strefy mieszkaniowe są realizowane zgodnie z zamierzeniami prywatnych inwestorów. Strefy mieszkaniowe powstają najczęściej w bliskim sąsiedztwie działek siedliskowych (rodzinnych) lub w miejscach wnioskowanych przez prywatnych inwestorów [3]. Nowo projektowana zabudowa uzupełnia istniejące nieciągłości zabudowy lub przewiduje strefy mieszkaniowe wzdłuż ciągów komunikacyjnych. Nie jest natomiast praktykowane projektowanie zabudowy tzw. drugiego rzędu, głównie ze względu na prywatny charakter własności gruntów. Stąd wniosek, iż możliwości dalszego rozwoju zabudowy terenów zaprojektowanych niewłaściwie w pierwszej fazie zagospodarowania, są znikome. Jedynie otwarte układy przestrzenne z prawidłowo zaplanowanym układem dróg oraz sieci technicznego uzbrojenia terenu dają możliwość racjonalnego zagospodarowania przestrzeni. Pojęcie skalowalności oznacza zdolność (pojemność) układu do ponoszenia kolejnych obciążeń związanych z dalszym zagospodarowaniem przestrzeni. Osiedla mieszkaniowe charakteryzu- 
jące się dużym stopniem skalowalności są możliwe do dalszej rozbudowy [6]. Tereny o niskiej skalowalności, są obszarami na których zasób przestrzeni został wyczerpany i nie może powstać nowa zabudowa. Skalowalność jest więc wielkością, która charakteryzuje możliwości rozwoju obszaru pod kątem przyjmowania (ponoszenia obciążeń) przyszłej zabudowy. Niekorzystnym z punktu widzenia rozwoju zrównoważonego jest zapełnianie terenami zabudowanymi i zurbanizowanymi wszystkich możliwych ciągów komunikacyjnych. Doprowadzi do stworzenia "zamkniętego" układu zabudowy, do utraty walorów krajobrazowych czy naturalnych korytarzy ekologicznych. Należy także pamiętać że wraz z rozwojem zabudowy pojawia się także problem ponoszenia obciążeń przez ciągi komunikacyjne a także problem wyposażenia oddalonych od siebie terenów w sieci technicznego uzbrojenia terenu.

Celem pracy jest wykazanie, że lokalna mikro koncentracja zabudowy, pomimo niemal ogólnej społecznej dezaprobaty jest niejednokrotnie jedynym wyjściem dla kreowania poprawnej polityki przestrzennej w gminie. Praca ma także na celu porównanie dwóch układów posiadających różne stopnie skalowalności - niski oraz wysoki. Wyznaczono parametry wpływające na ocenę przyjętych rozwiązań planistycznych, w tym skalowalności zabudowy. Do badań wykorzystano przestrzenne bazy danych.

\section{Obszar badań oraz metoda badawcza}

Badania przeprowadzono w oparciu o dwa obiekty badawcze zlokalizowane na terenie gminy Michałowice. Obszary badawcze nie zostały wybrane przypadkowo. Są to tereny zlokalizowane w strefie podmiejskiej Krakowa. Ponadto od kilkunastu lat są to obszary, na których można zaobserwować ożywioną dynamikę ruchu budowlanego [4]. Do analiz wybrano dwa obiekty które charakteryzują się odmiennym sposobem zabudowy. Pierwszy, na którym nowa zabudowa wpasowuje się w historycznie zastaną rozproszoną zabudowę zagrodową (funkcja rolnicza - Ryc.1. obiekt 1). Jej fizjonomia jest uwarunkowana w dużej mierze stosunkami własnościowymi. Drugi obszar to teren inwestycji developerskiej, w pełni zaplanowany do zabudowy i zagospodarowania (Ryc.1. obiekt 2).

W ramach analiz dokonano konfrontacji lokalizacji przyszłej i istniejącej zabudowy na obu obiektach a także porównano ustalenia miejscowych planów zagospodarowania przestrzennego. Podejmowana problematyka obejmuje badanie natężenia skupienia i rozmieszczenia obiektów budowlanych, kształtu i powierzchni przeznaczonych do inwestycji w Miejscowym Planie Zagospodarowania Przestrzennego (skr. MPZP) oraz możliwości jego rozwoju poprzez powtarzanie struktury zabudowy na innych obszarach, stopnia wypełnienia przeznaczonego terenu obiektami inwestycyjnymi, możliwością kaskadowego wypełnienia obszarów inwestycyjnych powtarzalnymi modułami rozwiązań projektowych. Wszystkie wymienione cechy autorzy rozumieją jako pojęcie skalowalności, czyli zdolności do ekspansji lub intensyfikacji zabudowy bez konieczności korekty obiektów już istniejących. 

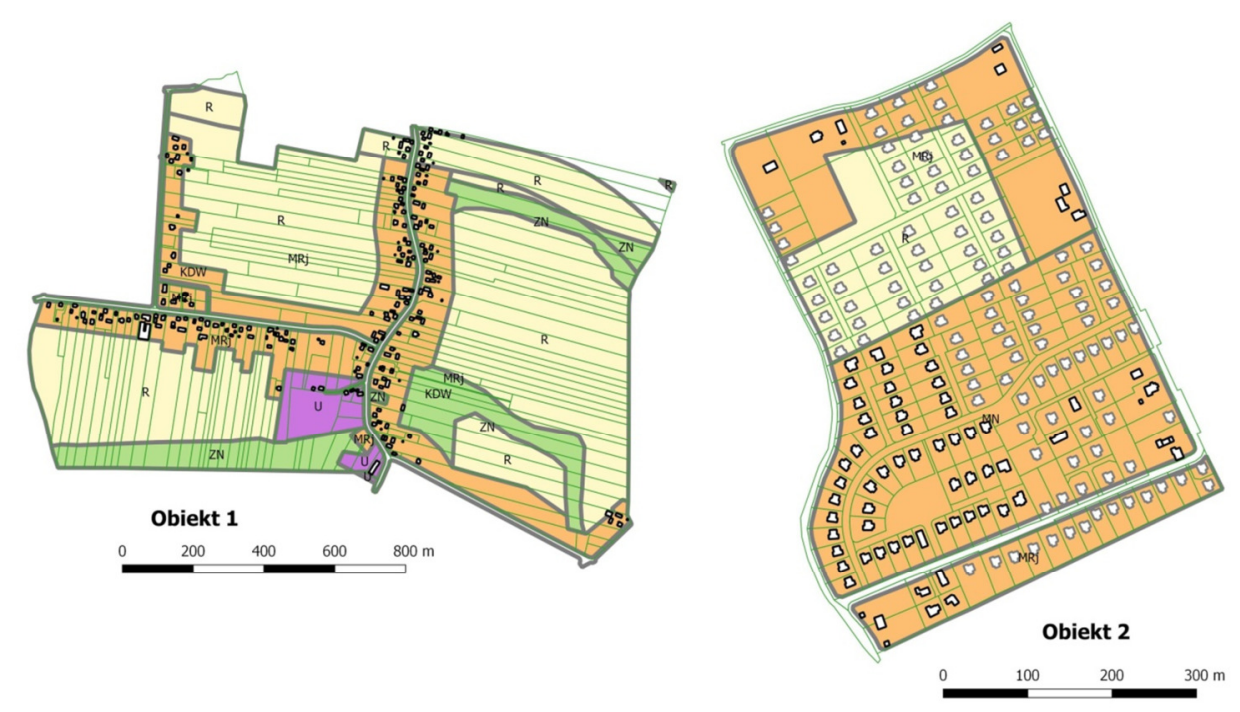

Ryc.1. Obszar badań 1 i 2 wraz z ustaleniami MPZP

Fig. 1. Study area 1 and 2 with Master Development Plan establish

Analizę porównawczą skalowalności układów przeprowadzono w oparciu o wybrane miary koncentracji zbioru punktów na płaszczyźnie obrazujące stan zagospodarowania przestrzennego obiektów. Z porównania obiektów wynika stopień odchylenia od siebie obu układów.

Do analiz posłużyły materiały źródłowe w postaci:

- mapy zasadniczej w formacie GML według stanu z kwietnia 2015 r.,

- mapy ewidencji gruntów i budynków w formacie SWDE, stan z kwietnia 2015 r.,

- rysunku Miejscowego Planu Zagospodarowania Przestrzennego (Ryc.2) w formacie wektorowym ShapeFile (SHP), który został zaimportowany do bazy SpatiaLite, według stanu na 2006 rok (publikacja MPZP).

Porównanie dotyczyło różnic w możliwości skalowalności obu układów. Różnice te mogą wynikać z wielu uwarunkowań, m.in. rodzaju praw własności gruntów podlegających planowaniu miejscowemu czy fizjograficznych, ograniczających sposoby przeznaczenia terenu na określone cele.

Analizując obiekt 1 pod kątem ustaleń miejscowego planu zagospodarowania przestrzennego w zakresie wyznaczenia stref zabudowy mieszkaniowej rolniczej można zauważyć przede wszystkim niekorzystne zjawisko przeznaczania coraz większych powierzchni rolnych na cele inwestycyjne.

Strefa MRj - zabudowy rolniczej obejmuje tereny wzdłuż wszystkich istniejących ciągów komunikacyjnych. W ten sposób powstała zamknięta enklawa terenów rolniczych pomiędzy układem dróg. W przypadku realizacji ustaleń tak przyjętego planu nie będzie zatem możliwości zachowania istniejących korytarzy ekologicznych, czy też utrzymania walorów krajobrazowych naturalnego 


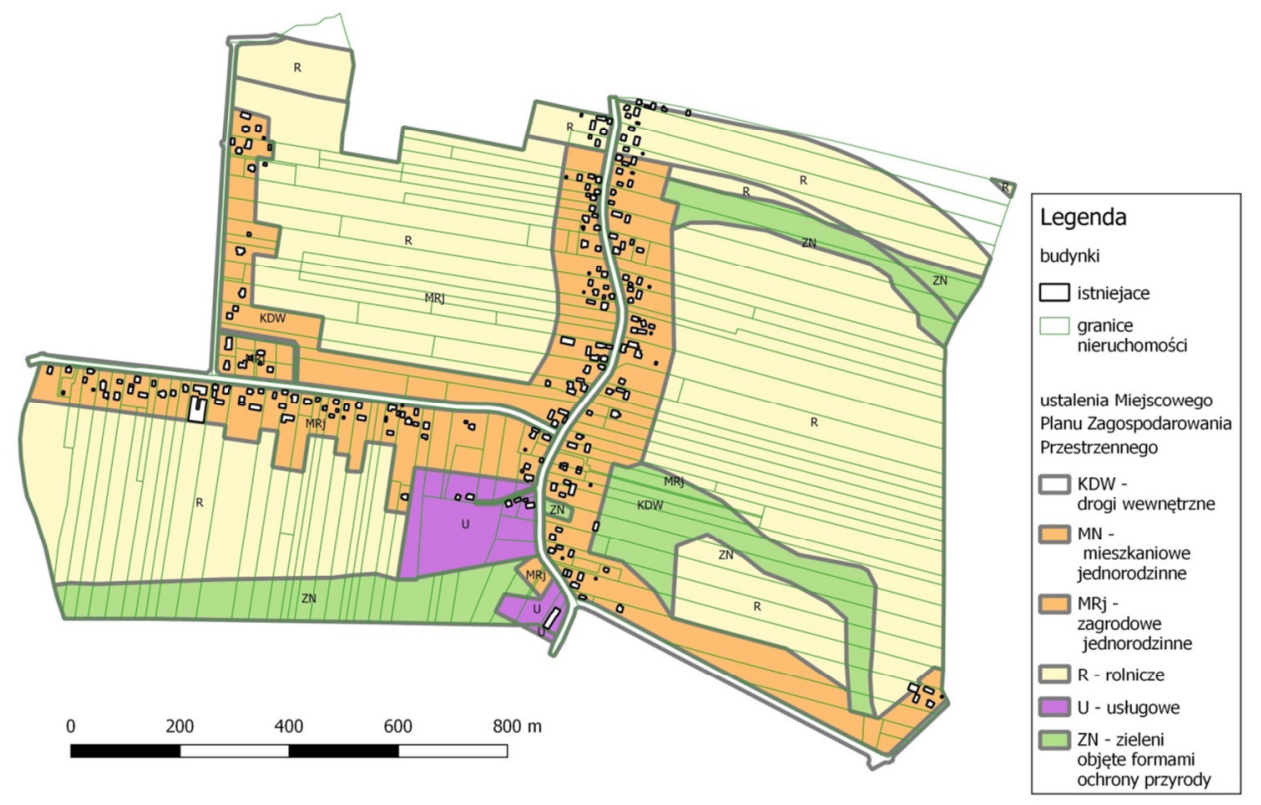

Ryc. 2. Ustalenia MPZP dla obiektu nr 1

Fig. 2. Master Development Plan establish for object 1

środowiska. Wyraźnie widać, iż powstaje zabudowa jedynie pierwszego rzędu. Powstanie zabudowy w drugiej linii za istniejącą zabudową będzie bardzo utrudnione, co wynika z braku odpowiednio zaprojektowanej sieci drogowej. Biorąc pod uwagę sposób wyznaczenia szerokości strefy MRj na poszczególnych działkach, można zauważyć, że w części przypadków strefy te zostały dwukrotnie powiększone tworząc nieregularną granicę pomiędzy strefą rolną i mieszkaniową. Dokonując porównania z obrazem zdjęć lotniczych badanego obszaru można zauważyć, iż taki przebieg granicy jest zgodny z użytkowaniem terenu (linią wyznaczaną przez sady znajdujące się bezpośrednio za zabudową rolniczą).

Szerokość wyznaczonej strefy MRj, ciągnącej się wzdłuż drogi głównej jest różna w różnych odcinkach. Na uwagę zasługuje również fakt, że w zapisach miejscowego planu zagospodarowania przestrzennego nie ma ustaleń dotyczących przeznaczania działek na określone cele w zależności od ich geometrii, wielkości, czy też usytuowania w stosunku do drogi. Na badanym obszarze pojawił się przypadek przeznaczenia obszaru działki (przylegającej całą długością) na cele zabudowy rolniczej (RM) pomimo iż, na tej działce już znajduje się zabudowa zagrodowa. W konsekwencji takiego działania projektanta istniejąca funkcja rolnicza terenów będzie zanikać na korzyść terenów zabudowanych.

Analizując rozmieszczenie oraz geometrię wyznaczonych w planie miejscowym terenów inwestycyjnych wykonany został szereg operacji geoprocessin- 
gu [2], mających na celu identyfikację obszarów możliwych do faktycznej zabudowy, w odróżnieniu stref wyznaczonych w planie miejscowym jako tereny $\mathrm{MN}$ - mieszkaniowe jednorodzinne, MRj - mieszkaniowe jednorodzinne zagrodowe oraz U - usługowe. Wymaga to uwzględnienia następujących założeń co do:

- wymaganej odległości względem granic nieruchomości,

- wymaganej odległości względem zabudowy sąsiadującej,

- usunięcia obszarów nie nadających się do zabudowy z powodu nieregularnego kształtu i zbyt małej powierzchni.

Przygotowane $\mathrm{w}$ ten sposób obiekty w bazie poddano działaniu narzędzia odcinania w oparciu o granice obszarów inwestycyjnych wyznaczonych w planie miejscowym a następnie usunięto szczątkowe poligony, których powierzchnia była mniejsza niż $30 \mathrm{~m} 2$ oraz wymiary boków mniejsze niż $8 \mathrm{~m}$. Proces technologiczny powstawania zidentyfikowanych obszarów przeznaczonych do zabudowy prezentuje poniższa rycina (Ryc. 3 ).

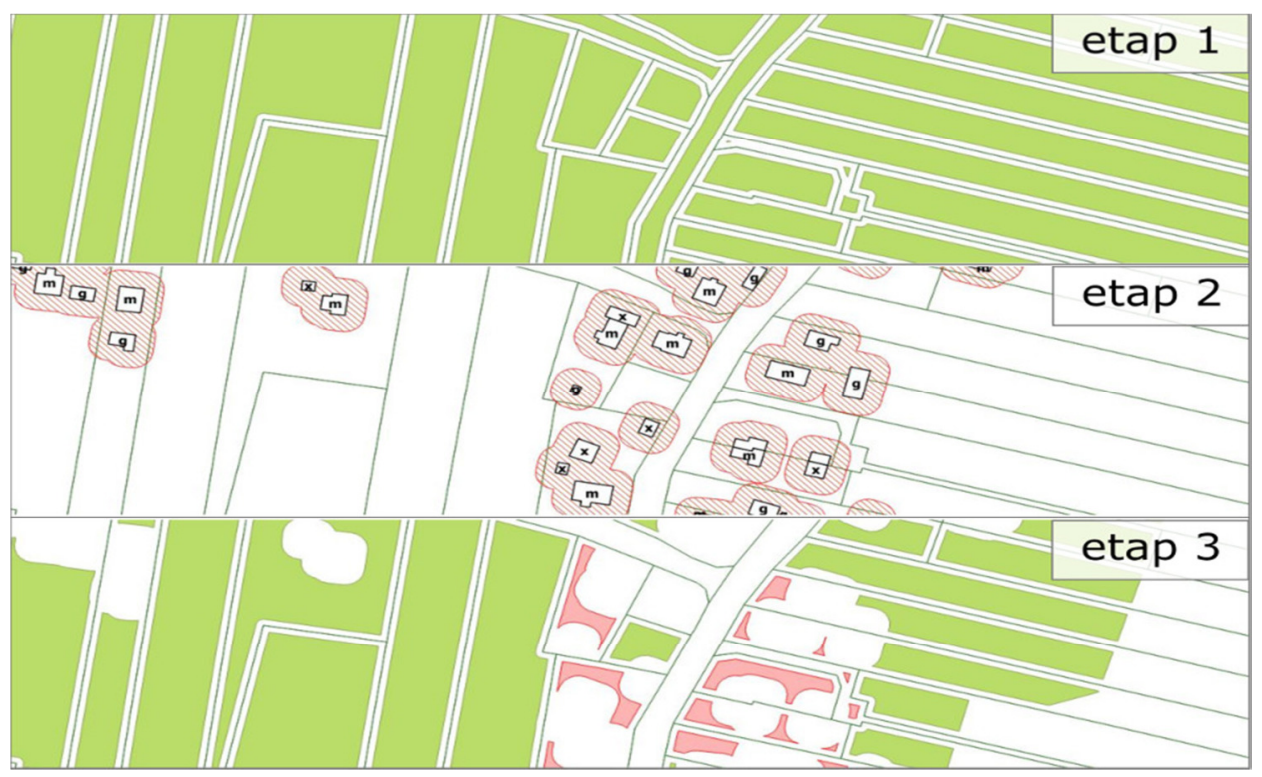

Ryc. 3. Identyfikacja obszarów możliwych do zabudowy

Fig. 3. Buildable areas identification

Etap 1: wydzielenie $\mathrm{z}$ nieruchomości stref wyjętych $\mathrm{z}$ zabudowy $\mathrm{w}$ oparciu o §12 Rozporządzenia w sprawie warunków technicznych, jakim powinny odpowiadać budynki i ich usytuowanie, wygenerowanie obiektów zmniejszonych o $3 \mathrm{~m}$ pasa wokół granic,

Etap 2: określenie stref wynikających z przepisów przeciwpożarowych i $\S 13$ i $60 \mathrm{w} / \mathrm{w}$ rozporządzenia - strefy 8 metrów wokół obrysu budynków, 
Etap 3: eliminacja stref, które z uwagi na zbyt małą powierzchnię $(<30 \mathrm{~m} 2)$ oraz niekorzystne wymiary boków $(<8 \mathrm{~m})$ i niekorzystny kształt - strefy oznaczone kolorek czerwonym; ograniczenie stref efektywnej zabudowy do linii rozgraniczających MPZP.

Przyjęto że wartością skuteczności wyznaczenia obszarów inwestycyjnych jest stosunek powierzchni stref wyznaczonych w MPZP do obszaru, który może zostać faktycznie zainwestowany. Podstawowym czynnikiem warunkującym badane zjawisko jest układ granic nieruchomości i wzajemne położenie nieruchomości budynkowych względem siebie. W większości przypadków zabudowie będą podlegać obszary oddalone od granic nieruchomości zgodnie z zapisami prawa budowlanego [13] i Rozporządzenia Ministra Infrastruktury w sprawie warunków technicznych, jakim powinny odpowiadać budynki i ich usytuowanie [14]. Minimalne odległości od granic nieruchomości zgodnie z $\S 12$ to $3 \mathrm{~m}$ dla ściany bez okien i $4 \mathrm{~m}$ dla ściany budynku z otworami okiennymi. Do obliczeń przyjęto odległość $3 \mathrm{~m}$.

Obszary przeznaczone w planie miejscowym na cele inwestycyjne mogą być również częściowo zabudowane. W takim przypadku o możliwości usytuowania budynku na działce decydują wymagania przeciwpożarowe oraz wymogi zapewnienia naturalnego oświetlenia (zgodnie z $§ 13$ i 60 warunków technicznych). Warunek naturalnego oświetlenia pomieszczeń przeznaczonych na pobyt ludzi (pokoi) uznaje się za spełniony, jeżeli między ramionami kąta $60^{\circ}$ wyznaczonego w płaszczyźnie poziomej, z wierzchołkiem usytuowanym w wewnętrznym licu ściany na osi okna pomieszczenia przesłanianego nie znajduje się inny obiekt przesłaniający w odległości mniejszej niż wysokość przesłaniania. Wysokość przesłaniania jest mierzona od poziomu dolnej krawędzi (parapetu) najniżej położonych okien budynku przesłanianego do poziomu najwyższej zacieniającej krawędzi obiektu przesłaniającego (dachu) [Rozporządzenie 2002]. Powyższe przepisy warunkują usytuowanie budynku w sposób dynamiczny. Im wyższe budynki sąsiadujące tym większa odległość pomiędzy nimi. Można w sposób uproszczony założyć, że dla budynków o wysokości do $12 \mathrm{~m}$ odległość pomiędzy nimi nie może być mniejsza niż $8 \mathrm{~m}$, po $4 \mathrm{~m}$ względem wspólnej granicy. Wygenerowano zatem strefy o szerokości $8 \mathrm{~m}$ względem obrysu budynków istniejących i wyłączono je z możliwości zabudowy.

Obliczona powierzchnia „efektywnej” zabudowy (Ryc. 4.) jest wynikiem zastosowania algorytmów geoprocessingu realizujących jedynie wybrane zapisy Prawa Budowlanego.

Powyższe reguły zastosowane zostały do testów na obiekcie 2, czyli osiedlu realizowanym przez developera. Powierzchnia przeciętnej działki budowlanej wynosi 9-10 arów gruntu, budynki są wolnostojące i powstała sieć wewnętrznych "ślepych" dróg dojazdowych wraz z drogami przejezdnymi osiedlowymi. Wyniki identyfikacji i kategoryzacji obszarów inwestycyjnych przedstawia rycina 5. 


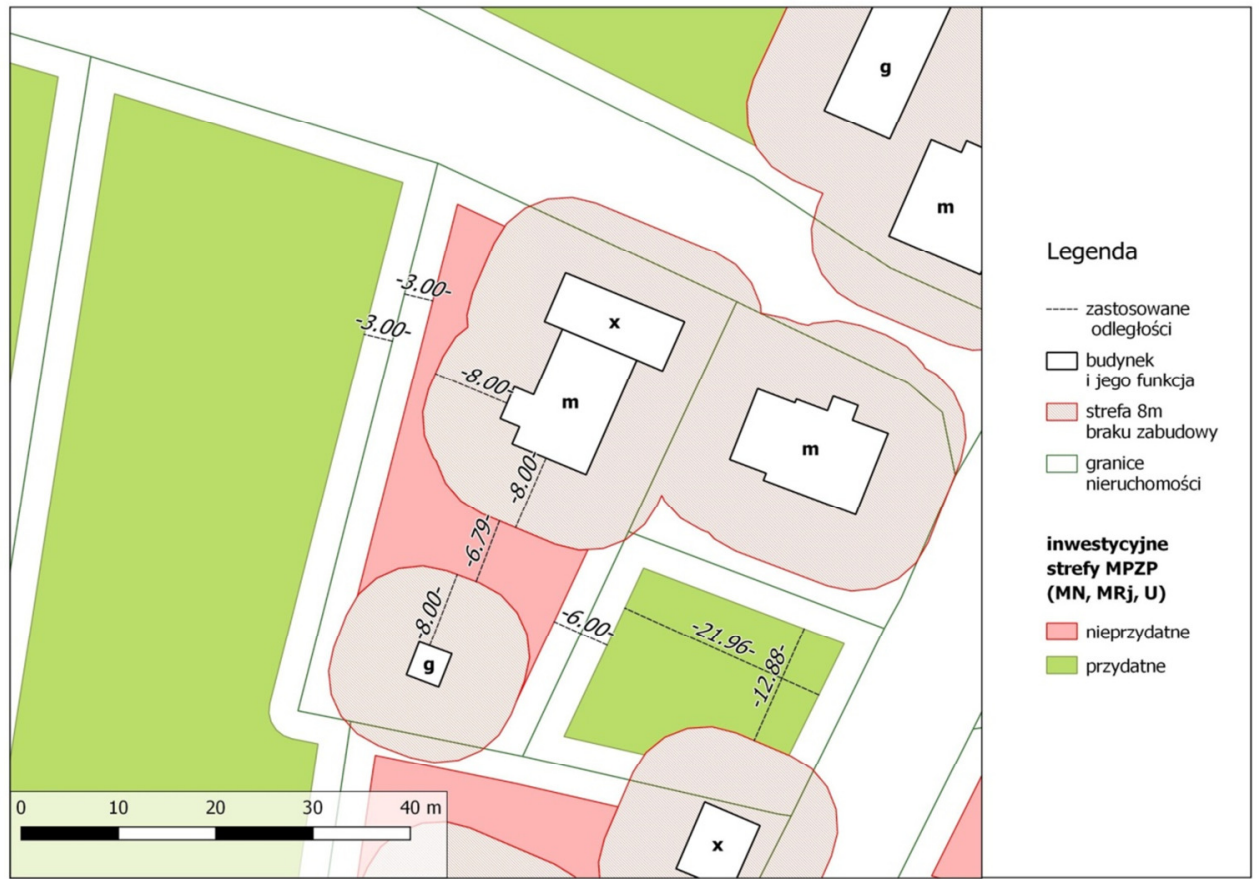

Ryc. 4. Strefy ustawowego wykluczenia obszarów z inwestycji

Fig. 4. The statutory zone exclusion areas of investment

\section{Wyniki badań}

Ocena poprawności określania obszarów zabudowanych powinna uwzględniać znaczny wpływ subiektywnego podejścia projektanta, organu zatwierdzającego miejscowy plan zagospodarowania przestrzennego oraz właścicieli nieruchomości, którzy zawsze są za przeznaczeniem swojej nieruchomości na cele inwestycyjne. Modele przedstawione w niniejszej pracy (obszar 1 oraz obszar 2) różnią się stanem własności, co warunkuje wszystkie dalsze efekty planistyczne. W obiekcie 1 - tradycyjnym układzie zabudowy prawo własności do przedstawionych nieruchomości posiada ok. 90 właścicieli. W obiekcie 2 jest ich 5 , z czego większość gruntów posiada developer. Obiekt 1 będzie wykazywał niezwykle dużą bezwładność w podejmowaniu decyzji o zmianie sposobu wykonywania własności, czego nie ma w obiekcie nr 1 . W przypadku projektowania nowych stref pod zabudowę w planie miejscowym, bardziej uzasadnione jest przeznaczanie większych zwartych kompleksów pod zabudowę. Bloki stref ograniczone drogami istniejącymi lub projektowanymi posiadają znacznie wyższe prawdopodobieństwo wypełnienia obszaru w całości inwestycjami (widoczne jest to na obu obiektach), natomiast w przypadku liniowego przeznaczania terenów na cele zabudowy wzdłuż dróg pełne zapełnienie obszaru jest mało prawdopodobne. 


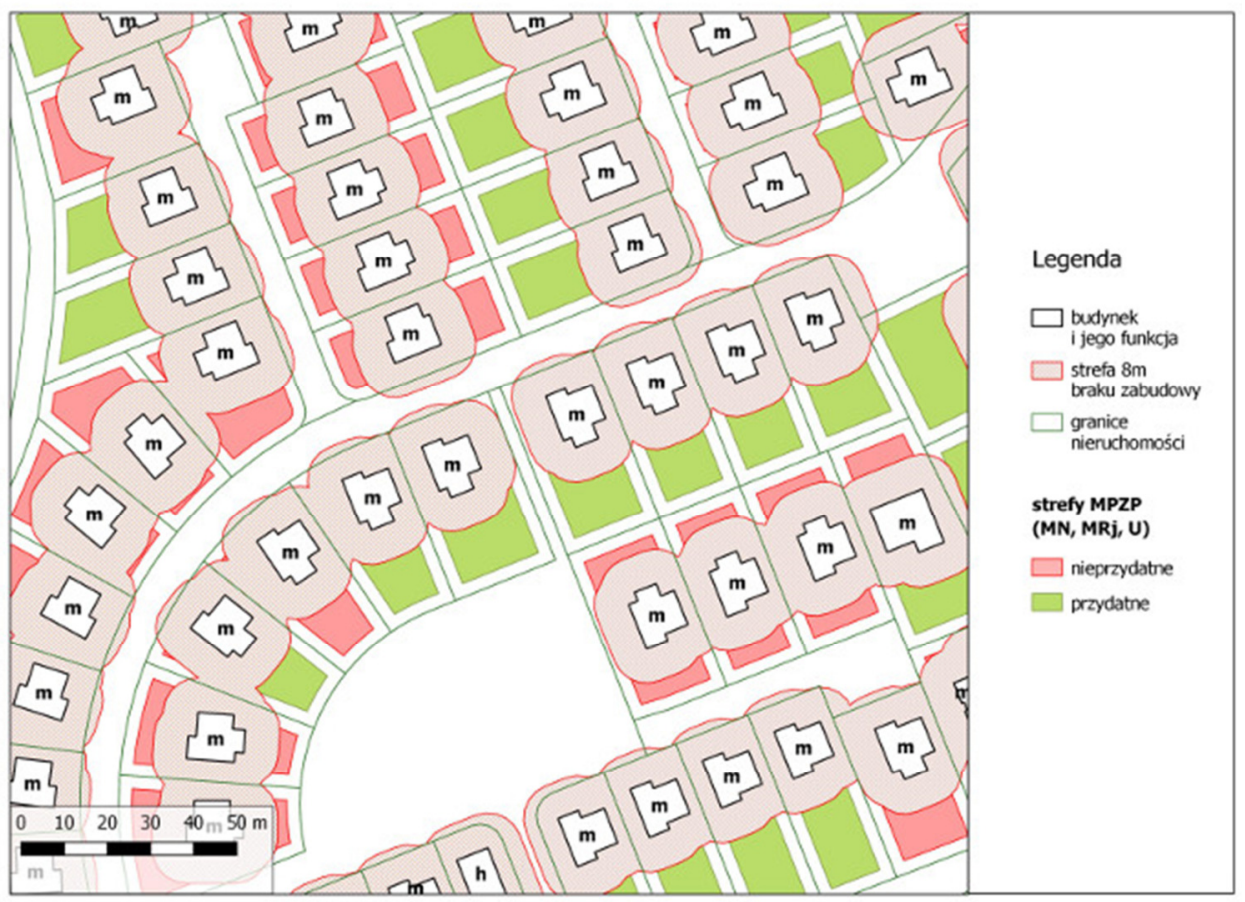

Ryc. 5. Identyfikacja stref i kategoryzacja obszarów inwestycyjnych na obiekcie 2

Fig. 5. Investment areas identification and categorization on the object 2

Dla celów poglądowych wykonane zostały obliczenia kategorii powierzchni inwestycyjnej dla porównywanych obiektów. Obliczone lub wygenerowane parametry mogą zostać uznane za części składowe miar oceny rozwiązań planistycznych oraz przyjętego współczynnika skalowalności. W poniższych zestawieniach jako podstawowa informacja została uznana powierzchnia obszarów przeznaczonych w planie miejscowym na cele inwestycyjne i "pozostałe". Wyodrębnione zostały obszary już zainwestowane, które stanowią grunty leżące bezpośrednio pod budynkami i budowlami oraz niezbędne strefy wykluczone z zabudowy wskutek obowiązujących przepisów Prawa budowlanego. Wskaźnik efektywnej powierzchni inwestycyjnej (kolor jasno zielony na rycinach) jest różnicą pomiędzy powierzchnią ogólną kompleksu inwestycyjnego a strefami wyłączonymi i nieefektywnymi. Za strefy nieefektywne przyjęto powierzchnie znajdujące się poza strefami wykluczonymi prawnie, lecz z uwagi na niekorzystną powierzchnię zwartą lub wymiary, niemożliwe do zabudowy (kolor jasno czerwony na rycinach). Dodatkowym współczynnikiem jest uzyskana wielkość, która informuje o tym ile przeciętnie powierzchni nieefektywnej ustawowo przypada na każdą nieruchomość w kompleksie. Ten parametr został nazwany „Współczynnikiem NieEfektywności Ustawowej” (skr. WNEU), i jest określony przez wzór (1): 


$$
\mathrm{WNEU}=\frac{\mathrm{P}_{\mathrm{k}}-\sum_{\mathrm{i}=1}^{\mathrm{n}} \mathrm{T}_{\mathrm{z}}-\sum_{\mathrm{t}=1}^{\mathrm{n}}-\mathrm{EPI}}{\sum_{\mathrm{i}=1}^{\mathrm{n}} \mathrm{t}_{\mathrm{z}}}
$$

gdzie: $P k$ - powierzchnia kompleksu w MPZP [ha],

$\sum T z$ - suma powierzchni obszarów zabudowanych ze strefami wynikającymi z §12, §13 i §60 Rozporządzenia [2002] /ha/,

$\sum E P I-$ suma powierzchni obszarów efektywnych inwestycyjnie /ha/,

$\sum T z i$ - liczba nieruchomości n kompleksie projektowym/jedn. niemianowana/.

Wyniki analiz przestrzennych zostały zaprezentowane $\mathrm{w} w$ postaci zestawień dla obiektów modelowych. Rozliczenie powierzchni inwestycyjnej w Obiekcie 1 wygląda następująco:

- obszarów wyznaczonych w MPZP do inwestycji - 39,8279 ha (100 \%),

- w tym już zabudowanych (wg reguł w $§ 12, \S 13$ i $\$ 60$ Rozporządzenia w sprawie warunków technicznych, jakim powinny odpowiadać budynki i ich usytuowanie) - 11,3460 ha (28,5\%),

- efektywna powierzchnia inwestycyjna - 23,1627 ha (58,2\%),

- nieefektywna powierzchnia inwestycyjna - 5,3192 ha (13,4\%),

- współczynnik niefektywności ustawowej - 0,0326 ha / nieruchomość.

Rozliczenie powierzchni inwestycyjnej w Obiekcie 2 wygląda następująco:

- obszarów wyznaczonych w MPZP do inwestycji - 21,2943 ha (100 \%),

- $w$ tym już zabudowanych (wg reguł w $\$ 12, \S 13$ i $§ 60$ Rozporządzenia w sprawie warunków technicznych, jakim powinny odpowiadać budynki i ich usytuowanie) - 11,8995 ha (55,9\%),

- efektywna powierzchnia inwestycyjna - 5,8299 ha (27,4 \%),

- nieefektywna powierzchnia inwestycyjna - 3,5649 ha (16,7 \%),

- współczynnik niefektywności ustawowej- 0,0184 ha / nieruchomość.

Z powyższego wynika, że obliczone parametry są bardziej korzystne w przypadku obiektu 2 . Taki stan został jednak osiągnięty po wspólnym opracowaniu projektu zagospodarowania działek dla wszystkich działek w kompleksie wyznaczonym w miejscowym planie na cele zabudowy. Gdyby analizie poddać obiekt 2 jeszcze przed wprowadzeniem zmian, obliczone parametry zapewne byłyby zbliżone jak w przypadku obiektu 1 .

\section{Wnioski}

Przeprowadzona analiza porównawcza obiektów badawczych pozwoliła na dokonanie oceny rozwiązań planistycznych pod kątem skalowalności zabudowy. Na podstawie przeprowadzonych analiz można stwierdzić, iż:

- Obecnie w na obszarach wiejskich w miejscowych planach zagospodarowania przestrzennego powstają strefy zabudowy mieszkaniowej, oparte o podstawowy układ komunikacyjny miejscowości, bez możliwości zabudowy tzw. dru- 
giego rzędu. Układ oparty o takie założenia oraz polityka planistyczna o charakterze „rabunkowym” doprowadzi do szybkiego wyczerpania przestrzeni inwestycyjnych. Może także prowadzić do ograniczenia przestrzeni naturalnej, lub do zamknięcia naturalnych korytarzy ekologicznych, czy też zmniejszenia walorów krajobrazowych poprzez umożliwienie zabudowy wzdłuż każdego ciągu komunikacyjnego.

- Przeprowadzone analizy wykazały odmienny charakter zwartych zabudowań deweloperskich, na których ze względu na działalność nastawioną na maksymalizację zysku, każdy metr przestrzeni jest w pełni wykorzystany, aż do pełnej zabudowy strefy.

- Znaczącą różnicą pomiędzy obiektami badawczymi jest fakt, że na obiekcie developerskim na obszarze nieco ponad 24 ha (obiekt 2) docelowo może powstać ponad 200 domów jednorodzinnych. Gdyby przyjąć sposób lokalizowania zabudowy według obiektu 1 ta sama liczba inwestycji musiałaby zająć znacznie większą powierzchnię.

- Biorąc pod uwage przeprowadzone analizy można stwierdzić, że skalowalność jest przede wszystkim zależna od przyjętych rozwiązań w procesie projektowania stref w planie miejscowym, ich geometrii i wzajemnego usytuowania. Projektowanie zwartych i większych powierzchniowo stref inwestycyjnych (kształt zbliżony do kwadratu) wraz z równoczesnym naniesieniem sieci komunikacyjnej daje lepszą możliwość przyszłej lokalizacji zabudowy w procesie inwestycyjnym niż ustalenie długich i wąskich stref przeznaczenia w planie miejscowym (wzdłuż dróg), których geometria znacznie ogranicza możliwości zabudowy.

- Projektowanie stref przeznaczenia terenu o charakterze inwestycyjnym jest mało efektywne w przypadku gdy występuje szachownica gruntów (własnościowa i użytkowania).

- Duże znaczenie w wyznaczaniu stref przeznaczenia terenu oraz możliwości zabudowy przyszłych stref inwestycyjnych posiada struktura własnościowa. Rozdrobniona struktura własnościowa w powiązaniu z obowiązującymi przepisami prawnymi powoduje duże "straty" powierzchni możliwej do zabudowy ze względu na ograniczenia zabudowy spowodowane przebiegiem granic nieruchomości. Rozwiązaniem dla tego typu zaistniałej sytuacji mogłyby być porozumienia mieszkańców posiadających działki w wyznaczonej strefie inwestycyjnej zmierzające do objęcia ich wspólnym planem zagospodarowania działek, nie zaś indywidualnymi planami dla każdego z mieszkańców z osobna.

- Standardy planistyczne powinny ograniczać dowolność geometrii i wielkości stref przeznaczenia terenu, uniemożliwiając zabudowę wzdłuż wszystkich dróg dojazdowych. Obok przyjmowanych w planie miejscowym wskaźników urbanistycznych powinna zostać na poziomie gminy ustalona maksymalna powierzchnia będąca w posiadaniu jednego właściciela, która może zostać przeznaczona na cele inwestycyjne. A o wyznaczeniu strefy zabudowy miesz- 
kaniowej nie powinna decydować jedynie informacja czy nieruchomość jest położona wzdłuż istniejącej drogi.

- Zastosowanie baz danych GIS umożliwiło szybkie przetworzenie informacji i wykonanie analiz przestrzennych stanu zagospodarowania przestrzennego obiektów oraz ich wzajemne porównanie.

- Ocena stanu zagospodarowania przestrzennego oparta na rozpoznaniu cech przestrzeni i występujących w niej zależności może zostać przeprowadzona w oparciu o aspekt skalowalności rozwoju zabudowy. Daje to możliwość wyznaczenia efektywności wykorzystania przestrzeni w procesie planowania przestrzennego.

\section{Literatura}

[1] Domański R. 2013. Gospodarka przestrzenna. Podstawy teoretyczne. Wydawnictwo Naukowe PWN, Warszawa.

[2] Gotlib D., Iwaniak A., Olszewski R. 2007. GIS. Obszary zastosowań. Wyd. PWN, Warszawa.

[3] Kwaśniak P. 2009. Plan miejscowy w systemie zagospodarowania przestrzennego. Wyd. LexisNexis, Warszawa.

[4] Leszczyńska M. 2010. System wspomagania decyzji optymalizujących rozwój marginalnych obszarów wiejskich. Acta Sci. Pol., Geodesia et Descriptio Terrarum 9(4) 2010, s. 37-48.

[5] Matysiak J. 2004. Człowiek a ład przestrzeni. W: T.J. Chmielewski (red.), Nowa jakość krajobrazu. Ekologia-Kultura-Technika, Komitet PAN Człowiek i Środowisko, Zeszyty Naukowe 36. Warszawa-Lublin, s. 59-69.

[6] Parysek J. 2008. Procesy suburbanizacyjne w aglomeracji poznańskiej. W: T. Kaczmarek, A. Mizgajski (red.), Powiat poznański - jakość przestrzeni i jakość życia. Bogucki Wydawnictwo Naukowe, Poznań, s. 71-90.

[7] Poniży L. 2008. Presja urbanizacyjna i jej wpływ na zmiany przestrzennej struktury użytkowania ziemi na wybranych obszarach podmiejskich Poznania. Problemy Ekologii Krajobrazu, T. XXII. 335-342.

[8] Prus B. 2012. Kierunki zmian przeznaczenia gruntów rolnych i leśnych w Polsce. Acta Scientiarum Polonorum. Geod. Descr. Terr. 11(2), 27-40.

[9] Sokołowski D. 1999. Zróżnicowanie zbioru małych miast i większych osiedli wiejskich w Polsce w ujęciu koncepcji kontinuum wiejsko-miejskiego. Wyd. UMK, Toruń, s. 31 .

[10] Springer F. 2013. Wanna z kolumnadą. Wyd. Czarna. Warszawa.

[11] Szulczewska B. 2000. Koncepcja rozwoju zrównoważonego jako podstawa strategii regionalnej - uwagi metodyczne. [w]: B. Szulczewska (red.), Przyrodnicze aspekty zrównoważonego rozwoju.

[12] Ustawa o planowaniu i zagospodarowaniu przestrzennym z dnia 27 marca 2003 r. [Dz.U. $2003 \mathrm{nr} 80$ poz. 717].

[13] Ustawa Prawo budowlane z dnia 7 lipca 1994 r. [Dz.U. 1994 nr 89 poz. 414]. 
[14] Rozporządzenie Ministra Infrastruktury w sprawie warunków technicznych, jakim powinny odpowiadać budynki i ich usytuowanie z dnia 12 kwietnia 2002 r. (Dz.U. $\mathrm{Nr} 75$, poz. 690).

Badania zrealizowane w ramach tematu $n r$ DS 3371/KGPiAK/2015 finansowanego z dotacji celowej Ministerstwa Nauki i Szkolnictwa Wyższego.

\section{PLANNING SOLUTIONS EVALUATION WITH THE USE OF SPATIAL DATABASE IN TERMS OF CONSTRUCTION DEVELOPMENT SCALABILITY}

\section{S u m m a r y}

This article presents the possibility of applying geomatic methods to evaluate the of drawn local development plans quality in terms of of their controlled development possibility. Scalability tested in this article is a measure of the possible duplication of planning solutions, roads communication, size plots optimizing, the development of suburban areas and rational use of possible housing areas. Spatial analysis was performed on GIS technology and functions implemented to spatial databases supporting. A free software: SQLite/SpatiaLite, SpatiaLite_GUI, QGIS was used to perform analises.

Key words: geoinformatics, free GIS software, spatial planning, master development plan scalability

DOI:10.7862/rb.2016.223

Przestano do redakcji: 15.07.2016 $r$.

Przyjęto do druku: 30.11.2016 r. 